\title{
DI WANG
}

\section{The Pandemic of Racist Capitalism Killed My Neighbor}

This story is for Jose, my dear neighbor, a queer Latinx man.

I.

My neighbor Jose was a Latinx man who was living alone during the COVID-I9 pandemic. The last time I saw him was April I 2020, a Wednesday afternoon, between 2 and $3 \mathrm{pm}$. I was sitting on our building's front stoop, finishing up a call with my friend in Quebec, Canada. At this point, New York City had been in quarantine for a little over two weeks. The stoop had become my new sacred place, and I went there to take breaks from writing.

That Wednesday, Jose was on his way out. As I heard the door open, I moved to the side to let him pass. Once he stepped onto the sidewalk, he turned around to say hi. He looked at my mask and, in his usual loving and playful manner, said: "You're wearing it the wrong way. The white part is the effective part." I smiled and realized that my face was covered. Then I nodded and told him that I knew.

My mind was racing. Since February, my entire family in China had repeatedly warned me and told me to wear a mask in public, but the issue of whether to wear a mask had already become politicized in the U.S. This simple matter has triggered many heated conversations in all of my social networks. The answer to this simple question can draw 
and redraw lines around one's identity - a Republican, a progressive, someone who can't think critically about governments, a person who hoards resources, or somebody who doesn't consider the community's wellbeing. By April, I - a recent Chinese immigrant to the U.S. - was torn about masks, too. I thought, what if Jose is right and the best way to wear it is inside out? Although I was unsettled, this short conversation ended with a typical goodbye: "Have a good day." "You too."

I watched his back disappear into the chilly sunlight of spring. A memory flashed before me: Jose told us that he had already lost ten friends in the pandemic, and that he was depressed. It was the early evening of March 27, 2020. My girlfriend and I were eating on the same stoop, and Jose was hanging out with the neighbors across the street. Report after report on the news continued to show that low-income Black and Latinx people in the U.S. were (and are) disproportionately impacted by the COVID-I9 pandemic and more likely to die compared to white people. Tears warmed my eyes as I whispered to myself, "I hope he is doing okay." I didn't know that it would be the last time I ever saw him.

\section{2.}

We lived in a brownstone in Brooklyn, New York. It was a three-floor building turned into three apartments, located only a few blocks away from the Atlantic Barclays Center. Jose was born and raised in the apartment on the first floor, where his family had lived since the r97os. The block's predominantly Black and Latinx community had watched him grow up: he was flamboyant in the I970s and I980s, became a father in the I990s, and came out later in life. While Brooklyn had gentrified, some of his closest childhood friends still lived on this block because their families bought their own brownstones. The community and people Jose cared about, and those who cared about him, represented the main reason for Jose fighting for his right to stay in the building. $\mathrm{He}$ once said that he would not know how to restart his life somewhere else. His whole life was on this block.

Jose always looked after his neighbors. When he learned that I had been suffering from allergies because of my apartment, Jose warned us 
that the building had a mold problem and that the landlord's only response was to put a fresh coat of paint on the wall. He invited us into his home to show us the mold there and told us that he would again file a 3 I I complaint about this issue. At that time, my girlfriend and I shied away from telling people we lived together because I was going back and forth between the U.S. and China for my fieldwork and was not named on the lease. Jose read our nervousness and immediately recognized our shared queerness. He told us, "no worries, we are all fam." That was how he came out to us.

Following that exchange, our queerness brought us closer, and Jose was like our queer older brother. We grew closer when his electricity went off and my girlfriend showed up at his door in her muscle tee. She found him standing by his door in his bathrobe, and he asked her to check on the power for him. We listened to his stories of lovers dying of AIDS, marrying women, some who still visited him for fun nights. He was warm, playful, and mischievous, like a queer auntie. We saw him educating people about $\operatorname{PrEP},{ }^{\mathrm{I}}$ heard him warning others to watch out for extra internet service charges, complaining about his ex-lover, who had petitioned for some trees to be planted on the street, which had now grown so tall they blocked his window view. As the sweetheart of our block, he took us in and made us feel part of the neighborhood.

\section{3.}

My neighbor Jose was a poor Latinx man who had to defend his basic dignity and rights to survive. From the I970s to 2008 , the brownstone was owned by a Black man who lived on the second floor. However, when the elderly owner passed away in 2008, his niece and nephew sold the brownstone to the current landlord. So began Jose's family's nightmare.

The new landlord is a large family that owns many properties all over New York City and has a history of evicting tenants through harassment. Upon purchasing the building, the new owner immediately registered it as a Limited Liability Corporation (LLC). This common practice allows landlords to hide their identities and prevents tenants from taking targeted actions against discriminatory practices. According to the open 
data on WhoOwnsWhat.nyc, by 2020, the portfolio of the family that owns the building recorded an estimated net loss of 159 rent-stabilized units since 2007 (gained o, lost 159), which represents 27.9 percent of the total portfolio.

Jose's family became the new owner's next target: they were going to be forced out of their rent-controlled unit. When we moved in on the second floor in the spring of 2018 , Jose had already moved back to the apartment to take care of his grandmother, who died of a heart attack later that year. Less than three weeks after his grandmother passed away, we saw an eviction notice on the building's front door, which said that Jose was illegally occupying the apartment. My girlfriend and Jose's childhood friend started to ask around and seek help from housing lawyers. Around this time, Jose told us that between 2008 and 2018, two members of his family died of heart attacks in the apartment: his uncle, and now his grandmother. Jose attributed this trend to the stress of the landlord's harassment. Later, we also learned that when Jose's grandmother fell ill, the landlord's manager would often text another tenant in the building to inquire about his grandma's "health."

Fortunately, when the landlord sued him, Jose won the case. To stand up to the whole system, Jose gathered every possible official document to prove that he had lived in the apartment for at least two years before his grandmother's death. Along with his driver's license and birth certificate, he collected all his bills, medical documents, tax forms, and 3 I I complaints against the landlord, all of which listed the building as his address and dated back to 20I6. He even kept his first-grade report cards, and his first-grade teacher still lived across the street. In a system set up to humiliate every mistake a disadvantaged person can make, Jose had to take extreme care to be able to prove the simple truth: this had been his street since birth.

On the good days, Jose regarded this laborious task with good humor. He complained that no one came to claim his late uncle's DJ equipment, which took up too much space in his apartment. He pouted when his friends made fun of him for refusing to change his ID picture because his old picture just looked so good. 
More often than not, however, the stress of the landlord's harassment overwhelmed him. Every time Jose heard strangers coming into the basement, he texted us to ask if we knew them, because he was worried that the landlord had sent them. In the past decade, Jose's family had contended with mold, the heat being cut off, an unsafe electric grid, and so on. Jose had to be extremely cautious about every aspect of living in the building. When Jose sent in his rent, he deliberately chose to send it via money order to prevent the landlord from saying that he had not paid. Still, we learned that the landlord had not claimed some of Jose's money orders, opting to return them to him instead. In contrast, our rent check had been accepted without issue during the same time period. Later we also found out from his friends that the constant threat of eviction caused him so much stress that he would sometimes disappear for a few days. Further, when he felt depressed, he could not bear to go into the government office for housing assistance, even though it was just a bus ride away from our building.

Because of the COVID-r9 pandemic, New York City's housing courts had been closed since March I6. While the city put an eviction moratorium in place, without rent relief at a time of soaring unemployment rates, many people feared what would happen when the eviction moratorium ended and eviction cases could be heard again. At the same time, shutting down the housing courts did not stop the harassment of tenants; in Jose's case, it had the opposite effect. In March of this year, the landlord once again attempted to reach a deal with Jose to make him move out. In the midst of this harassment, my girlfriend and I thought about organizing a rent strike and moving out, despite the difficulty of moving during quarantine, but we could not bear the thought of leaving Jose alone to deal with our landlord.

\section{4.}

In mid-April, my girlfriend and I each received a stimulus check from the Internal Revenue Service (IRS) as part of the U.S. government's (so far) one-time payment to mitigate the pandemic's economic impact. We decided to donate some of our checks to local movement organizations 
and to give some of the money to Jose. While my social media feeds were flooded with tips on how to work from home, the quarantine had cost Jose his job as an in-home medical aide, and he once mentioned that he was unsure how he would pay the rent the coming month. In the month of April, according to the U.S. Bureau of Labor Statistics, the number of people who filed unemployment claims in the U.S. rose by 15.9 million and reached 23.I million. ${ }^{2}$ We were not sure if Jose had applied or even qualified.

We texted him. No reply.

We had last received a text message from him on March 24 at I2:03 p.m. After we missed his call, Jose texted my girlfriend to check on us: "Just calling to make sure you are okay." He usually texted us back within a day.

We started calling him more frequently. No answer. A few days later, all the calls went straight to voicemail.

"Maybe he was at his uncle's place and didn't have enough money to pay his cellphone bills?" Jose told us all his close family had died of heart attacks, leaving only him and his younger uncle. Alas, we did not have the uncle's name or contact information.

"Should we contact the landlord?" We knew that Jose himself would never allow the landlord to enter his unit, given all the tragedies that the landlord's harassment had caused in his family. In the end, we asked the building superintendent to check on him, and we discovered that Jose did not allow anyone who worked for the landlord a copy of the keys to his apartment.

Following our friends' advice on how to text in this situation, we added a sentence on Friday April 24, indicating that if he did not respond by Monday, we were going to call for backup.

Every time we came in or left the building that weekend, we knocked on his door. No answer.

On Monday, April 27, after debating all of our options, we filed a missing person report through nyc.gov/CovidMissing, a new system called the Unified Victim Identification System (UVIS), which was activated in response to the COVID-r9 pandemic. The system served to file 
a report about a friend or loved one who might be missing due to $\mathrm{CO}$ VID-I9; we filed the report with the slim hope that it would not mean getting the police involved. In less than a day, a detective called us back. I held my breath as my girlfriend spoke on the phone with the detective. The last thing we wanted to do in this situation was to call the police.

We were scared. Jose was a dark-skinned, big-boned Latinx man who suffered from depression and a heart condition. In the eight years I have lived in this country, there has seldom been any good news when the police show up to conduct wellness checks, especially for Black and Brown people. I remembered the story of Kenneth Chamberlain Sr., who had a severe heart condition; he accidentally set off a medical-alert pendant and was shot to death when, the police said, he refused to open the door. I thought of many others like him. The current system provides few to no safe options for checking on people like my neighbor Jose.

The same day, April 27, a rotting smell started to waft into our bathroom. We became more worried. We ran around our block, knocking on doors, trying to find people we had seen him hanging out with. Some said they had seen Jose a few days before. Others said they had just seen Jose over the weekend, smoking on the stoop. But no one could give us any exact information; during quarantine, everyone had lost track of time.

\section{5.}

On Tuesday, April 28, Jose's childhood best friend came to our building after she had learned from her mother that two Chinese girls across the street were looking for Jose. The morning of Wednesday, April 29 Jose's therapist showed up at the front door because she was concerned that Jose was missing appointments, which he had never done before. Jose's friend decided that we had no other choice but to call the police. Around noon, two police officers, both of whom were Black, arrived. As they walked towards our building, I overheard a neighbor whisper, "oh good, it is two brothers."

An elderly Latinx man who lived across the street walked towards our building to see what was going on and started talking to one of the 
two Black officers: "What is your last name? ... Oh, I thought you were Puerto Rican."

The police officer politely said no.

The elderly man laughed, and as he walked away from our building, he took a slight turn back to us and said, "When I grow up, I want to become a police officer."

His daughter yelled back, "Oh man, you are not growing up. You are growing out now!"

Everyone burst out in laughter, cutting the tension in the air so much that I almost felt the elderly man's move was intentional. It seemed like a skill practiced to ease interactions with the police, a secret weapon that one had to deploy in order to survive.

Soon, many more higher-ranking police officers showed up at our building, and our neighbors formed a half-circle around the front stoop. The racial make-up of the police force became whiter, and we all grew quieter. The police officer in a white uniform finally agreed it was necessary to break down the door to enter the apartment. However, before that was done, he asked my girlfriend to call the landlord for permission to force the door open and to secure the landlord's promise to fix the door afterward. Everyone was frustrated.

As I watched my girlfriend conveying messages between the landlord and the police officer because the landlord had refused to commit to anything, I was almost frozen. I viscerally understood the police's function as protecting property over human lives. If the mission was to protect Jose, it should not happen like this. Why did the call for Jose's rescue have to wait for his worst enemy's permission? I felt sick. I wanted to strongly voice my demand that the police skip whatever it was they were doing instead of helping Jose. But all I could manage to say to my girlfriend was, "baby, just give your phone to the police officer."

In the end, the police decided to go through the back windows. I understood this as an attempt to minimize any damage to the building. The rotting smell broke the bad news of Jose's death through the front door as two police officers in full protective gear walked out. They said they found Jose's ID but could not recognize the body. This brought 
the neighborhood back to jokes about Jose's youthful-looking, neverchanged ID picture. This time, though, the laughter was crushed by sadness.

My memory of the rest of the afternoon is hopelessly jumbled. I remember that Jose's uncle showed up. He showed me a bag for the Key Food market in his pocket; he said he had just gotten off work and was going to buy some groceries. He must have also told the police that he did not have a key to the apartment, either. I recall that I wanted to hug him, to hug everyone, but I could not because of the pandemic. The police must have also told him that he had to look out for their call. Because most of the city's morticians were tied up with COVID deaths, he had to wait.

Gradually, people left. Jose's uncle decided to wait on our building's stoop. Wanting to give him some space, my girlfriend and I went back into our home and left the building's front door open. We heard him call out Jose's nickname, and he cried out that now he was the only one left in the family. These words were so heartbreakingly familiar. I had heard the same words from Jose. As night fell, neighbors brought candles and flowers to the stoop. We brought down coffee and food for Jose's uncle. At some point, the rain started pouring, but I cannot remember the exact order of things.

It must have been after midnight when the morticians finally came to collect Jose's body. We went downstairs. Most of the neighbors I had seen during the day came back. Although my vision was blurred by tears, I could see the lights coming on in our elderly neighbors' apartments across the street. I stood watching my neighbor Jose being moved into a huge van. My girlfriend said to me, "he was so loved by so many people."

\section{6.}

Our lease ended the next day, May I, 2020. The landlord refused to renew any of the leases in the building, claiming they could not go into the office. They had no problem collecting the rent checks mailed to the office, however. Within a week, we learned that the landlord would soon gut and renovate the building. They asked if they could send workers 
into our apartment to take measurements, and told us that they would double the rent afterward. At the same time, a rotting smell started to permeate the whole brownstone through the leaks in the pipes caused by all those years of neglect. When we complained, we were told that no one could move anything from Jose's apartment before the housing courts reopened. I thought to myself, at least the landlord could not break into Jose's room to throw his home out onto the street. I felt almost happy that at least some form of Jose's life could spread throughout the building, and that Jose would finally have the apartment, protected by law and guarded by the police, all to himself for a while. But it was too little, too late. The looming eviction crisis and the lack of rent relief meant that landlords like Jose's and mine were the only winners in this situation.

We moved out of the brownstone on June I, 2020. A day later, we found out that the landlord's son had already advertised the furniture we left behind on Craigslist.

\section{7.}

My neighbor Jose was a brave queer who did all he could to protect his rights. He stood up for himself and neighbors like us, and never backed down.

On the night of May 29, people gathered at the Atlantic Barclays Center to demand justice for George Floyd and protest systematic racism. As the crowd chanted, "Whose street? Our street!" and headed toward Fort Greene Park, I was thinking of you, Jose. I am inspired to fight in your name. 
DI WANG is a feminist researcher and advocate from China. She is a $\mathrm{PhD}$ candidate of Sociology at the University of Wisconsin-Madison, USA, with a focus on LGBTQ rights, legal mobilization and social policy. Her research has been informed by her ten years of experience as a women's and LGBTQ rights advocate. Using family as a focal point, her dissertation investigates the globalization of LGBTQ rights, with an empirical focus on China. Her work is committed to research-based advocacy and the advancement of analytical tools for social change. Her writings have been published by, among others, Law and Social Inquiry, China Law and Society Review, Chinafile.

\section{NOTES}

I. As the Center for Disease Control and Prevention (CDC) defines it, "Pre-exposure prophylaxis (or PrEP) is a way for people who do not have HIV but who are at very high risk of getting HIV to prevent HIV infection by taking a pill every day." See cdc.gov/hiv/risk/prep/index.html.

2. See the U.S. Bureau of Labor Statistics for more information: https://www.bls. gov/opub/ted/2020/unemployment-rate-rises-to-record-high-I 4-point-7-percentin-april-2020.htm. 